\title{
Collective Complicity in War Crimes. Some Remarks on the Principle of Moral Equality of Soldiers
}

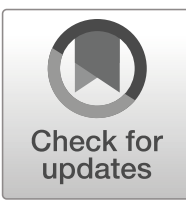

\section{Adam Cebula ${ }^{1}$}

Received: 2 April 2019 /Revised: 11 November 2019 / Accepted: 8 April 2020/

Published online: 20 May 2020

(C) The Author(s) 2020

\begin{abstract}
The article critically analyzes one of the central assumptions of Michael Walzer's version of just war theory, as presented in his main work devoted to war ethics. As requested by the author of Just and Unjust Wars, the controversial nature of the principle of the moral equality of soldiers is revealed by discussing the actual course of events of a historical military conflict - namely, the outbreak of World War II, one of the main issues dealt with in Walzer's book. The exclusion of individual responsibility of people involved in a military operation which finds no moral justification seems to entail a number of consequences that put a heavy burden on Walzer's overall model of military ethics. In order to ensure the necessary level of coherence of just war theory one may need to modify Walzer's principle of the moral equality of soldiers - at least in relation to the participants of total war.
\end{abstract}

Keywords War ethics · Just war theory · Moral equality of soldiers · War propaganda · Individual moral responsibility

Published in 1977, the famous Just and Unjust Wars by Michael Walzer built on traditional theorizing on the ethics of war, as initiated over 16 centuries ago within Christian moral philosophy. In addressing a whole set of questions centring around the ethical construal of military action, Walzer proposed a significant revision of some of the standard responses which had usually been given to them. The modified version of the theory of just war has been critically

Adam Cebula

a.cebula@uksw.edu.pl

1 Wydzial Filozofii Chrzescijanskiej, Uniwersytet Kardynala Stefana Wyszynskiego,

Warsaw, Poland 
revisited several times: its main critics highlighted the controversial character of a number of proposals offered by Walzer, such as the suspension of war conventions in a "supreme emergency" situation ${ }^{1}$ - and in some cases they called into question the most basic assumptions underlying the theory. ${ }^{2}$ In order to defend his position, Walzer usually points out the fundamental incommensurability, as he sees it, between the methodology of contemporary military ethics and his own approach, which stresses the pre-eminence of the historicallyinformed - as opposed to purely theoretical - means of philosophical inquiry into the phenomenon of war. ${ }^{3}$ The purpose of this paper is to attempt a critical analysis of one of the key elements of Walzer's theory, i.e., the principle of the moral equality of soldiers, while respecting the most basic terms of discussing war proposed by the author of Just and Unjust Wars.

One of the fundamental assumptions of Walzer's theory is the logical and axiological independence of the criteria applicable in justifying the initiation of war (jus ad bellum) and the rules governing a morally appropriate conduct of military operations (jus in bello). Only states, by breaking the rules of jus ad bellum, can be culpable of the crime of aggression (military operations directed against another state/s), while individual soldiers fighting on either side of the frontline preserve equal moral status: "[T]he war itself isn't a relation between persons but between political entities and their human instruments. These human instruments [...] are "poor sods, just like me« [the 'me' here referring to any soldier fighting in a conflict], trapped in a war they didn't make. I find in them my moral equals." "Individual soldiers fighting on behalf of their states are not in any way embroiled in or burdened by the rightness or wrongness of the cause they are fighting for. At the same time, all participants of military operations, regardless of the legitimacy of the reasons for fighting set out by the particular parties to a conflict, are obliged to observe the rules specifying the morally permissible methods of conducting combat, i.e., the rules of jus in bello. The uppermost among the latter is the principle forbidding attacks on non-combatants ${ }^{5}$ - war, according to Walzer, who is

\footnotetext{
${ }^{1}$ See, e.g.: Ch. Toner, Just war and the Supreme Emergency Exemption, in: The Philosophical Quarterly 55 (2005) 221, 545-561; D. Statman, Supreme emergencies revisited, in: Ethics 117 (October 2006), 58-79.

${ }^{2}$ See, e.g.: J. McMahan, The Ethics of Killing in War, Ethics 114 (2004): 693-733. McMahan's critique of Walzer's theory, continued in his subsequent publications, has made him arguably the most prominent opponent of the model of war ethics proposed in Just and Unjust Wars.

${ }^{3}$ See: M. Walzer, Just and Unjust Wars (Postscript. A Defense of Just War Theory), New York, Basic Books, 2015, 335-346.

${ }^{4}$ M. Walzer, Just and Unjust Wars, New York, Basic Books, 2015, 36.

${ }^{5}$ Membership in this category is decided on the basis of a functional relationship between a specific type of activity and the actual course of military operations. For more on the distinction between combatants and non-combatants see the seminal paper by E. Anscombe: E. Anscombe, War and Murder, in: Nuclear Weapons: A Catholic Response, ed. W. Stein, London and New York, 1961, 45-62.
} 
followed in this respect by the majority of contemporary scholars, is state-organized "combat between combatants". 6

The basic premise of Walzer's version of just war theory has long been a subject of intense debate among scholars dealing with war ethics. The most famous polemical position with respect to the views of the author of Just and Unjust Wars is that of the wide-ranging critique of his theory formulated by Jeff McMahan. ${ }^{7}$ The main reason for moral inequality between just and unjust combatants is, according to McMahan, the inability of unjust combatants to meet the requirement of proportionality (one of the key rules of jus in bello). In defending the principle of moral equality, Walzer's supporters impute "revisionist" reasoning with essential ahistoricity, which to a large extent invalidates its conclusions. The examples presented by the opponents of Walzer's theory as evidence of its inherent flaws are not, in the opinion of Walzer's defenders, properly embedded in a historical context. They are also characterized by elemental indeterminacy typical of thought experiments, and the very assumption of their analogy to real-life situations is fraught with a series of epistemological simplifications. ${ }^{8}$ By contrast, Walzer's arguments are grounded in analysis of historical facts. In his view, the moral equality of combatants is sufficiently confirmed by the events that took place in Europe during the trials held at the conclusion of the Second World War. The fact that the proceedings focused on, among other things, the behaviour of thousands of Dutch people who had collaborated with the Nazi regime, whereas none

\footnotetext{
${ }^{6} \mathrm{M}$. Walzer, Just and Unjust Wars, op. cit., 42. For earlier just war theorists jus ad bellum and jus in bello were naturally connected The correction of the predominant views on the origin of soldiers' moral inequality thesis (overlooking its deep embedment in the classic versions of just war theory) was recently undertaken by Uwe Steinhoff (U. Steinhoff, Rights, Liability, and the Moral Equality of Combatants, Journal of Ethics (2012) 16, 342-346). While making the same point with respect to the traditional approaches to war ethics, Gregory Reichberg indicates the emergence during the Middle Ages of what he calls a "regular war paradigm", which extended the legal permissibility of military engagement to all sovereign belligerents as well as all combatants fighting on the opposite sides of such conflicts. (G. M. Reichberg, The moral equality of combatants..., G. M. Reichberg, The moral equality of combatants - a doctrine in classical just war theory? A response to Graham Parsons, Journal of Military Ethics, 2013 Vol. 12, No. 2, 182-187). What is notable, the primordial character within the just war theory paradigm of the ascription of guilt to combatants of the unjustly warring party is admitted by Walzer himself. For more on the acknowledged parallels and discrepancies between his own theory and the views of Polish medieval scholar Paul Vladimiri, see: M. Walzer, Just war and holy war. Again, in: Ethical Perspectives, 24 (2017) 1, 8).

${ }^{7}$ J. McMahan, The Ethics of killing in war, Philosophia (2006) 34, 27, 28.

${ }^{8}$ See: M. Walzer, Response to McMahan's Paper, in: Philosophia 34 (2006), 43-45; Idem., Just and Unjust Wars (Postscript. A Defense of Just War Theory), New York 2015; M. Rigstad, Putting the War Back in Just War Theory. A Critique of Examples in: Ethical Perspectives, 24 (2017) 1, 123-144. Walzer recently reiterated his criticism of abstract theorising about war in his response to the empirical study investigating the American public's views on the principle of moral equality of combatants. M. Walzer, On Reciprocity and Practical Morality: A Response to Sagan and Valentino, in: Ethics \& International Affairs, 33, no.4 (2019), 445-450.
} 
of the cases concerned the activities of German and Italian soldiers, undergirds, in Walzer's opinion, the appropriateness of according the latter the privilege of moral equality with the soldiers of the Allied forces. The members of German military units involved in direct aggression against a number of sovereign states in the years 19391945 are thus granted equal status with their opponents, fighting in defense of their countries: "the soldiers [...] were doing the done thing, what everybody else was doing, what their parents and friends, teachers and pastors, and the leaders of their country, insisted was the right thing to do - and so in fact we didn't compel them to explain themselves, one by one. Once again, we collectivized their legal and moral status."

\section{Walzer's Moral Equality Thesis and the Course of the German Campaign of September 1939}

One of the key issues that arise in the context of the above dispute is the possibility of challenging the most controversial - as I am inclined to believe assumption of Walzer's theory, while maintaining a position which is either neutral with respect to the two opposing views, or even favours the historicalreality-focused model of war ethics. In other words, the essential question should concern the resilience of the principle of the moral equality of combatants to a critique which seriously takes into account the requirement to substantiate it with references to some actual - not merely hypothetical - course of events in a historically documented armed conflict. For a Polish - or more broadly: Central or Eastern European - observer of the primarily AngloAmerican debate on the moral aspects of war, the obvious challenge is to examine the historical accuracy (and thus also - by Walzer's own terms the basic coherence) of the major thread running through Just and Unjust Wars, i.e., Walzer's discussion of a number of moral issues related to the crucial developments of the Second World War. To put it directly: is one really entitled to claim - in the context of the results of historical research on WWII - that the Nazi German soldiers attacking Poland on the 1st of September 1939 maintained essentially the same moral status as the members of the Polish military formations who resisted them?

The acceptance - in accordance with Walzer's express intent - of the criterion of the legal responsibility of soldiers, as employed in the post-war criminal trials, as proof of the equal moral status of the soldier-attackers and the soldier-defenders-of-their-own-country does not seem convincing. The purely pragmatic reasons for using such a criterion, which dovetails perfectly with the corresponding international conventions on the employment of means and methods of warfare in armed conflicts, are emphasized as part of the polemics Jeff

\footnotetext{
${ }^{9}$ M. Walzer, Response to McMahan's Paper, in: Philosophia 34 (2006), 44. In his contribution to a recent war ethics symposium he tries to circumscribe the ethical significance of the soldiers' moral equality thesis, but even in light of his newly formulated caveats it retains its essential normative weight: "When I claim that soldiers who fought an unjust war should not be punished after the war but just sent home, I am not saying anything about what their friends and neighbors, or any of the rest of us, should think of their conduct. My own judgment is that what they did was not wrong; the injustice of the war was not their responsibility. Traditional just war theory does not require me to say anything more than that." M. Walzer, On Reciprocity and Practical Morality, op. cit., 33, no.4 (2019), 446.
} 
McMahan tabled against the author of Just and Unjust Wars. ${ }^{10}$ Regardless of the apparently inconclusive character of Walzer's argument, serious doubts emerge over the plausibility of the very attempt to regard standard procedures of criminal law as the formula for the ultimate moral rectification of war crimes committed during World War II. A much more reliable test of the validity of Walze"s Moral Equality Thesis as it is applied to the war of 1939-1945 would be, therefore, to consider it directly against the background of events comprising, in the first place, the victorious campaign of the Nazi German armies in the early autumn of 1939.

The attack on Poland on September 1, 1939 was essentially the first combat engagement of the military forces of the Third Reich. Previously the German Wehrmacht "had become used to strolling into countries that had already given themselves up, such as Austria and Czechoslovakia". "Even if one agrees with Walzer's defenders that McMahan's interpretation of an armed attack on a sovereign state as (at least) one phase of an unjust war in which the unjust combatants "cannot participate without doing wrong", is fraught with the typical "revisionist" idealization of the realities of a military conflict, the actual beginning of the German army's operations in Poland still seriously undermines the possibility of applying to it Walzer's key distinction between jus ad bellum and jus in bello. Contrary to the long upheld belief about the outbreak of World War II - still persistent, for some reason, in certain circles of contemporary historians - the actual first target of the Wehrmacht on September 1, 1939 was not the Polish military base situated near Gdańsk on the Westerplatte peninsula, but the small town of Wielun far to the south, inhabited by less than 1600 people and - most importantly - devoid of any military significance. As a result of the Luftwaffe air raids launched against Wielun, on September 1 at 4:40 am, about 1200 inhabitants were killed, hundreds more were wounded, and $70 \%$ of the town's buildings were completely destroyed.

Recently published studies devoted to World War II, such as T. Snyder's Bloodlands, acknowledge the bombing of Wielun as the first strike of the German Wehrmacht in 1939: "The German terror began in the sky. At 4:20 in the morning on 1 September 1939, the bombs fell, without warning, on the central Polish city of Wielun. The Germans had chosen a locality bereft of military significance as the site of a lethal experiment. Could a modern air force terrorize a civilian population by deliberate bombing? The church, the synagogue, the hospital all went up in flames. Wave after wave of munitions fell, seventy tons of bombs in all, destroying most of the buildings, and killing hundreds of people, mostly women and children. The population fled the city; when a German administrator arrived, there were more corpses than live people. Throughout western Poland, scores of towns and villages met a similar fate. As many as 158 different settlements were bombed." ${ }^{\prime 3}$ A significant voice in the process of the gradual discovery by Western historiography of the real nature of the German aggression against Poland in 1939 is that of Norman Davies, the author of the most

\footnotetext{
10 These reasons are, according to McMahan, the inability of any nation, or even an international institution, to conduct fair trials of such a large number of people, the inevitable tendency of war winners to retaliate against the soldiers of the defeated army, and the danger of prolonging war conflicts in view of the anxiety of the soldiers of the losing army about their fate (deterring them from surrendering to the winners). J. McMahan, The Ethics of Killing in War, Ethics 114 (2004), 731; J. McMahan, Killing in War: A Reply to Walzer, in: Philosophia 34 (2006), 50.

${ }^{11}$ T. Snyder, Bloodlands. Europe between Hitler and Stalin, New York, Basic Books 2010, 120.

12 J. McMahan, The Ethics of Killing in War, Ethics 114 (2004), 696-697 .

13 T. Snyder, Bloodlands. Europe between Hitler and Stalin, New York, Basic Books, op. cit., 141.
} 
renowned English-language history of Poland (God's Playground. A History of Poland, Oxford: Oxford University Press 2005): “On 1 September 1939, the Luftwaffe targeted Wielun for its very first bombing raid. The bombs started falling by some accounts at 4.30am and by others at 4.40am; at all events several clear minutes before the opening salvo at Westerplatte. About 1,290 townspeople were killed in their beds. Three-quarters of the town was pulverised. The casualty rate was more than twice as high as Guernica or Coventry. But hardly anyone outside Wielun recalls it. The 50,000 people killed by German bombs in Warsaw in September 1939, and the 200,000 killed in similar circumstances during the Warsaw uprising of 1944, serve as Poland's major memories of bombing. For whatever reason, Wielun - to use the technical phrase - is not a lieu de mémoire."14

The bombing of Wielun - as opposed to the destructive air raids on cities such as Warsaw, Rotterdam, Coventry, and Dresden - made its way into the WWII historiography very slowly. ${ }^{15}$ The main reasons behind this belated acknowledgment of the initial military operation of Nazi Germany in the late summer of 1939 are apparently related to the swift development of events during the campaign and - above all - the unprecedented scale of atrocities against civilians which immediately followed the invasion of Poland by the German army. The historical record leaves no doubt that Wielun, situated at a distance of a dozen or so kilometres from the Polish-German border, was by no means a legitimate target for aerial bombing: the first defence line, organized by the Polish military command along the Warta and Widawka rivers, stretched $30 \mathrm{~km}$ west of Wieluń, no military troops were stationed in the town or its vicinity, and the town did not accommodate any militaryrelated industries. ${ }^{16}$ The inhabitants of Wielun were exposed to three waves of intense bombings - after the first attack launched at 4:30-4:40 am the raids were resumed at 6:00 am and completed at 1:00 pm the same day. ${ }^{17}$ The whole operation was carried out by a number of squadrons of the German Air Force stationed near the border and commanded by Generalmajor Wolfram von Richhofen, who as the commander of the German Condor Legion had ordered the bombing of Guernica during the Spanish Civil War. ${ }^{18}$ Completely unprepared for the attack, the town witnessed scenes of carnage and utter chaos from the very first moments of the bombing. The greatest number of casualties was inflicted in the central part of Wielun, the area inhabited mostly by the town's Jewish community, which thus suffered the largest losses in the raids. ${ }^{19}$ One of the first objects targeted by the bombers was the local hospital (according to the testimony of some of its employees, during the general preparations for war underway since the late summer of 1939 the roofs of the hospital's buildings had been marked with Red Cross emblems). ${ }^{20}$ The interpretation of the

\footnotetext{
${ }^{14} \mathrm{~N}$. Davies, We must not forget the real causes of the war, in: The Independent, 28.08.2009, http://www. independent.co.uk/voices/commentators/we-must-not-forget-the-real-causes-of-the-war-1778973.html [accessed 30 April 2020].

15 The comprehensive description of the case has been the result of detailed research carried out by a number of Polish historians. The author of the most in-depth analyses of the Wehrmacht's first strike in 1939 is Tadeusz Olejnik. An extensive presentation of his findings accompanied by the review of literature on the bombing of Wielun is offered in his most recent publication: T. Olejnik Wieluńska hekatomba. Poczatek wojny totalnej [The Hecatomb of Wieluń. The beginning of a total war], Wieluń, 2014.

${ }^{16}$ Ibid. 13

${ }^{17}$ Ibid. 27.

${ }^{18}$ Ibid. 14-15, 23-25, 116-117. J. Böhler, Der Überfall. Deutschlands Krieg gegen Polen. Frankfurt: Eichborn, 2009, 102.

${ }^{19}$ According to data from 1938, the 5238 Jewish residents of Wielun comprised more than one third of the town's population. T. Olejnik Wieluńska hekatomba, op. cit., 39, 43, 115.

${ }^{20}$ Ibid. $30-37,119$.
} 
bombings as a tragic mistake of the Luftwaffe remains profoundly unconvincing as its proponents fail to explain the whole sequence of the raids, with the attack resumed at least twice at 2- and 7-h intervals. The "tragic mistake" theory also renders incomprehensible the first of the German airmen's reports on the operation, which specifies the town of Wielun as the operation's main target (Hauptziel $<<$ Ort Wielun $>>$ ) and confirms the successful accomplishment of the mission ( $<<$ Angriffserfolge: Ziel vernichtet, Brande beobachtet $>$ ) while asserting the absence of any military troops in the town $(<<$ keine besondere Feindbeobachtung $>>)^{21}$

Initiating warfare - even in the case of an unquestionable war of aggression - with an attack aimed directly at a group of defenseless civilians, and thus breaking the most basic principle of jus in bello, cannot be described by reference to the conceptual framework underlying Walzer's theory. A meticulously planned military operation carried out by an elite unit of an exceptionally disciplined army, the murderous air raid on Wielun on September 1, 1939 cannot, moreover, be "excluded" from the sequence of events that constituted the institutional act of aggression of one sovereign state against another. A military aggression which encompasses the intentional killing of non-combatants must therefore appear from the point of view of Walzer's theory to be a hybrid phenomenon. According to the theoretical model proposed in Just and unjust wars - which assumes an unequivocal separation of jus ad bellum from jus in bello - aggression (breaking the rules of jus ad bellum) is "the only crime states can commit against other states." 22 And although the subjects that, according to Walzer, are obliged to adhere to the rules specifying permissible ways of conducting military operations are both states and individual soldiers, ${ }^{23}$ the basic logic of his argument concerning jus in bello rests on the idea of individual responsibility: crimes that violate these rules are directly attributable to particular soldiers and their superiors. In the case of the German invasion of Poland in 1939, the international community's obligation to prosecute individual perpetrators of war crimes (to a large extent - for many reasons, including the above-mentioned "pragmatic" ones - unfulfilled ${ }^{24}$ ) does not, of course, raise any doubt on the grounds of Walzer's theory. The key question in the analysis of the first military operation of Nazi Germany during World War II (as well as regarding the great majority of German military operations in Central and Eastern Europe in the period of 1939-1945) is, however, whether the very participation in this undertaking on the part of both those who perpetrated specific war crimes, as well as those who were not directly involved in them - was not morally reprehensible in and of itself.

The coordinated action of an aggressor state, aimed simultaneously at killing soldiers fighting in defense of their country as well as at murdering civilians of the attacked state, is certainly something entirely different from the "classic" armed attack by one state against another, considered by the author of Just and Unjust Wars to be the most basic form of violation of jus ad bellum (in the course of which more or less isolated violations of jus in bello may unfortunately occur because of the very nature of military violence). It should be noted that while defending the principle of the moral equality of soldiers - the cornerstone of the clear-cut separation between jus ad bellum and jus in bello - a number of supporters of the principle do allow for some exceptions to its universal applicability. According to

\footnotetext{
${ }^{21}$ J. Böhler, Der Überfall, op. cit., 102; T. Olejnik Wieluńska hekatomba, op. cit., 24-25, $27,119$.

${ }^{22}$ M. Walzer, Just and Unjust...., op. cit., 51.

23 Ibid., 127.

${ }^{24}$ J. Böhler, Auftakt zum Vernichtungskrieg. Die Wehrmacht in Polen 1939. Frankfurt am Main: Fischer, 2006, 163-164, 180.
} 
Graham Parsons, the principle in question, highly significant as it is for the preservation of the public character of war, applies to all military conflicts and generates a moral obligation on the part of soldiers to implement the orders of their states' leaders, "[p]rovided that the war is not obviously unjust". Such a concession, in Parsons's view, does not pose a threat to the integrity of a state's political power structures (military action being the most sophisticated type of state-organized law enforcement measures) since "it is consistent with the existence of fully realized and effective political authority to hold that on some occasions agents of the authority ought to disobey orders to commit life-threatening violence but only in certain extreme cases". ${ }^{25}$ A corresponding restriction on the universality of the soldiers' moral equality thesis is imposed by Yitzak Benbaji in much more explicit terms: the permissibility of being a soldier - with all the normative consequences of the "moderated morality"-based "division of moral labour" - extends only to "decent" societies. By introducing the concept of societies' "decency" Benbaji intends to "exclude societies founded on radically immoral principles, such as Nazi Germany; soldiers who carried out the Nazi aggression had no contractual right to do so, because the Third Reich had no right of national defence to begin with". ${ }^{26}$ The argument of Uwe Steinhoff is circumscribed at the outset by the author's caveat limiting the actual effectiveness of the principle of the moral equality of soldiers to "many, if not most modern wars". One may wonder if the implied exceptions to the effective moral equality of combatants should not include all conventional defensive wars fought within the attacked state's territory: the probability of innocent people's (non-combatants') rights being infringed by just combatants declines in such cases to zero (unless one opts for a curious interpretation of the culpable threat posed by the soldiers of the attacked state as directed also against their own countrymen). With the acceptance of such an account of defensive wars, the number of wars characterized by the moral inequality of combatants will definitely rise far above the narrow margin of all the military conflicts they supposedly amount to (in Steinhoff's view). What is notable, the historical examples provided by Steinhoff do not include the German-Polish war of 1939, although to illustrate his point about the illegitimate threat posed by just combatants to enemy civilians he makes reference in one of his papers to the Second World War's Allied soldiers endangering the lives of innocent people on the German side. The case in which "the combatants of the just side (perhaps a weak invaded country) do not pose any unjust threat, typically because they lack the means or the will to attack the enemy in the enemy's territory (therefore posing no threat to the innocent on the enemy side) and do not threaten their own innocents" is exemplified in the same paper by "more or less neo-colonial wars fought by the United States and some of its allies in Nicaragua, Grenada, and arguably in Afghanistan and Iraq". 27

The necessity of finding for the German campaign of September 1939 a different conceptual formula than Walzer's jus ad bellum vs. jus in bello distinction is highlighted by the fact that bombing the homes of the sleeping residents of Wielun was by no means a "singularity" during the five-week operation of the Wehrmacht troops in

\footnotetext{
${ }^{25}$ G. Parsons, Public war and the moral equality of combatants, Journal of Military Ethics, 2012 Vol. 11, No. 4, 300, 314 .

${ }^{26}$ Y. Benbaji, The war convention and the moral division of labour, The Philosophical Quarterly, 2009, Vol. 59, No. 337, 601 .

${ }^{27}$ U. Steinhoff, Rights, Liability, and the Moral Equality of Combatants, Journal of Ethics (2012) 16, 340341; U. Steinhoff, Debate: Jeff McMahan on the Moral Inequality of Combatants, The Journal of Political Philosophy: Volume 16, Number 2, 2008, 226.
} 
Poland. The actual course of the campaign, gradually discovered in recent years by Western historiography, leaves no doubt as to the systematic character of the violations of the most basic war conventions by the military forces of the Third Reich initiating WWII. ${ }^{28}$ According to the findings of historians, in the early autumn of 1939 the fate of Wielun was shared to a greater or lesser extent by hundreds of Polish towns and cities $^{29}$ : the German air force massacred entire columns of civilians fleeing towards the eastern part of the country ${ }^{30}$; German troops carried out thousands of executions of civilians - both while conquering and temporarily conceding individual fragments of the battlefield ${ }^{31}$; captured Polish soldiers were shot dead (not less than three-thousand of them were killed in this way) ${ }^{32}$; German soldiers perpetrated massacres, rape, and robberies in the captured cities (aimed especially at their Jewish population). ${ }^{33}$ Both the scale and frequency of these incidents clearly indicate that they were part and parcel of

\footnotetext{
$\overline{28}$ The dynamics of the multi-stage debate held in the field of German historiography about the criminal nature of the operations of the Wehrmacht has recently been described by the German historian Jochen Böhler. (J. Böhler, Wojna z Polska w 1939 r. w historiografii zachodnioniemieckiej [The German-Polish war of 1939 in German historiography], in: Spojrzenie na Polski Wrzesien 1939 [A perspective on the Polish September campaign of 1939], ed. T. Kondracki, Warszawa 2011). Böhler is the author of several studies devoted to crimes committed in Poland by the Nazi German army (Böhler, Jochen (2006). Auftakt zum Vernichtungskrieg. Die Wehrmacht in Polen 1939. Frankfurt am Main: Fischer; Böhler, Jochen (2009), Der Überfall. Deutschlands Krieg gegen Polen. Frankfurt: Eichborn) In Polish literature, the ground-breaking book devoted to this subject was published in the 1960s by Szymon Datner (Sz. Datner, 55 dni Wehrmachtu w Polsce. Zbrodnie na polskiej ludności cywilnej w okresie 1.IX - 25. X. 1939 [55 days of the Wehrmacht in Poland. Crimes against the Polish civilian population in the period of September 1 to October 25, 1939], Warszawa, 1967.) The findings of both authors are cited by T. Snyder in his Bloodlands.

${ }^{29}$ J. Böhler, Der Überfall, op. cit., 99, 179-182.

${ }^{30}$ Ibid., 94.

31 J. Böhler, Auftakt zum Vernichtungskrieg, op. cit. 149-152,

32 J. Böhler, Der Überfall, op. cit., 164-168, J. Böhler, Auftakt zum Vernichtungskrieg, op. cit. 171-180.

33 J. Böhler, Der Überfall, op. cit., 202-205. J. Böhler, Auftakt zum Vernichtungskrieg, op. cit. 181-187; 189200. T. Snyder, Bloodlands. Europe between Hitler and Stalin, New York, Basic Books, op. cit., 119-123. Szymon Datner lists the following criminal methods of warfare employed by the Wehrmacht, or by other German police and paramilitary formations, for whose operations in Poland in the period from September 1, 1939 to October 25, 1939 (i.e., until the transfer of administration over the occupied territory to the civil authorities) the German armed forces were fully responsible:
}

- $\quad$ "military aggression (invasion) without the declaration of war required by international law

- $\quad$ air bombing raids and artillery fire directed against unprotected cities

- other terrorist methods of aerial warfare

- criminal methods of warfare at sea, such as the sinking of neutral ships and passenger ships without warning, shooting on the high seas drifting or floating crew members of sunken warships, cargo ships or passenger ships

- murdering prisoners of war on the battlefield, at collection points, during transport and in permanent camps

- $\quad$ murdering civilians in captured cities, towns and housing estates, taking civilians as hostages, killing civilian hostages in retaliation for acts which they did not commit

- forcing prisoners of war and civilians to participate in hostilities by using them as "human shields" against the attacks of their countrymen, deploying such "human shields" around their own forces, placing hostages in important military installations to protect them from enemy attack

- burning villages, towns, cities and housing estates; destroying property - both public and private without military necessity, with the objective of sowing terror; organized and individual plunder of public and private property

- forcing prisoners of war and civilian population of the occupied country to perform actions prohibited by international law, i.e., directed against their homeland, etc./" Sz. Datner, 55 dni Wehrmachtu w Polsce. Zbrodnie na polskiej ludności cywilnej w okresie 1.XI - 25. X. 1939, Warszawa, 1967, 48. 
the military strategy pursued by the Nazi German troops with utmost consistency. Admitting (together with Walzer) that the participants of this operation - even those (possibly a majority of Nazi Germany's combatants) who refrained from direct involvement in those atrocities - could preserve a moral status equal to that of the defenders of the murdered civilians, does not therefore seem to be a plausible account of the German-Polish war of 1939.

\section{Three Types of Participation in a Total War}

In considering the moral taintedness of participation in a total war - exemplified by the Nazi German attack on Poland - one should differentiate between three types of contribution to the violations of non-combatants' immunity that are characteristic of such a military operation. The first type embraces all actions posing (resulting in) an immediate threat to civilians which are undertaken by the direct perpetrators of those crimes. The second consists in any activity in the arena of the direct deployment of armed forces which might reasonably be thought to facilitate intentional physical harm inflicted on civilians. Apart from cases involving obvious complicity in such crimes, this type also covers engagement in regular combat, provided the combatants are aware of the systematic anti-civilian atrocities taking place during the war. The third type of individual participation in a total war - seemingly unrelated in a morally (or, sometimes, even causally) relevant manner to the perpetration of violence against noncombatants - amounts to being exclusively engaged in ordinary combat (hostilities targeting only enemy soldiers), or discharging duties related to military logistics, i.e., transportation, food supply, acquisition of facilities, etc., without any knowledge of the character of the war. While the first two ways of engaging in anti-civilian atrocities leave no doubt as to some level of culpability on the part of their direct perpetrators/ people facilitating their infliction, it is also the third mode of participation in a NaziGerman-like war of aggression that seems to deserve moral condemnation due to the functional support for war crimes which it necessarily generates.

In line with Walzer's general argument, in the case of "standard" state-to-state aggression, the soldiers of the aggressor state are not responsible for the war as soldiers. If they are citizens of a democratic country "old enough to have shared in the decision to fight" they share the responsibility for the decision in question with "all those men and women who voted for [the war] and who cooperated in planning, initiating and waging it". Even then, however, they cannot be held responsible for "doing the actual fighting": only those of them who are involved in breaching the rules of jus in bello (or issue orders to do so) become morally guilty of this crime. ${ }^{34}$ The principle of discrimination between combatants and non-combatants - the latter enjoying the essential immunity from being targeted during any kind of military operation - lies at the heart of jus in bello. With "few moral principles [...] more widely and viscerally affirmed", the principle - called "Moral Distinction" - has recently been given a somewhat restrained formulation by Seth Lazar. According to Lazar "In war, with rare exceptions, killing noncombatants is worse than killing combatants." 35 Considered with reference to the

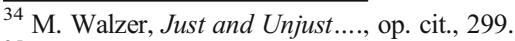

${ }^{35}$ S. Lazar, Sparing Civilians, Oxford University Press, 2015, 2.
} 
wide variety of circumstantial complications possibly resulting from different types of military conflicts, the general proscription against harming civilians may indeed require some qualification - especially in view of Lazar's intentions "to be ecumenical with different theories of liability." ${ }^{36}$ There can be no denying, however, that when applied to military aggression of the Nazi German type - an undeclared invasion of an independent country without any reasonable justification - the principle of discrimination should be upheld in its most restrictive wording: harming civilians during such an operation is always unqualifiedly wrong. This is especially so in the case of the direct targeting of people completely uninvolved in the attacked country's defence maneuvers, and remaining outside the scope of what might possibly be deemed the invaders'military-strategy-related collateral damage. The perpetrators of such harm can undoubtedly be regarded as culpable of the first of the three types of contribution to the violations of non-combatants' immunity mentioned above. It comes as no surprise that in analyses of war crimes against civilians the case of the Nazi invasion of Poland is often taken into account in an explicit manner. Seth Lazar presents the massive killings of civilians during that operation as the paradigm case of such crimes: "In the Battle of the Bzura, September 1939, the German 10 th Army crushed several infantry divisions of the Polish Army. The Wehrmacht killed perhaps 20,000 Polish soldiers. At the same time, Nazi forces were carrying out Operation Tannenberg, slaughtering 20,000 Polish civilians over two months, shot and buried in mass graves. No doubt, the invading army wrongly killed those Polish soldiers. But killing those civilians was still worse."37 What such an account of the beginning of WWII leaves insufficiently clear, though, is that it was parts of the same armed forces of the Third Reich that were responsible both for the victorious Blitzkrieg of 1939 and the efficient slaughter of Polish noncombatants which was carried out simultaneously.

With the systematic character of anti-civilian harm underlying its widespread infliction on such a large scale, an important question arises concerning possible forms of complicity in related war crimes extending to members of the military other than the direct perpetrators of those crimes. The responsibility for violating the rights of civilians must obviously be attributed to all individuals who, even while not participating directly in such acts, may nevertheless be described as their more or less apparent facilitators. The discussion of the second type of contribution to the systematically inflicted anti-civilian hostilities should take into account parallel analyses addressing the issue of the liability of soldiers fighting on the unjust side of ordinary military conflicts (the side violating jus ad bellum). What is emphasized in most of these analyses is that for such unjust soldiers to become liable to being killed, not only must their contribution to the achievement of the war's unjust ends be of a causal nature, but also the causality in question must meet certain quantitative/qualitative criteria. Defined in a variety of ways, the latter are sometimes combined with additional qualifications specifying the level of culpability on the part of the said combatants. A valuable insight into the spectrum of possible relevance thresholds for individual contributions to the violations of jus ad bellum may be gained by considering the change of opinion on that matter declared by Cecile Fabre: from taking this threshold to be a "high causal

\footnotetext{
36 Ibid., 63.

37 The second number quoted by Lazar is much lower than the figures specified by historians. See, e.g., the number of victims of the bombardment of Warsaw referred to by T. Snyder (page 6 above).
} 
significance" of a combatant's contribution to the war's end, coupled with his sufficient "moral responsibility" for that contribution, ${ }^{38}$ she moves to interpreting it in strictly causal terms, with even minimal contributions counting as relevant, as long as the agents making them "would be liable to less-than-lethal force if they acted alone" ("if an agent's contribution is such that he has lost his right not to have force used against him"). ${ }^{39}$ Seth Lazar considers varying degrees of causal significance characteristic of one's contribution to unjustified threats to be sufficient for one's liability to lethal harm. In each case of such liability, however, some level of individual responsibility on the part of the unjust combatant is also necessary. With both causal contribution to unjust harm and some agential involvement in its infliction being crucial in deciding about a combatant's liability, "at least one of those elements must be relevantly substantial. A substantial causal contribution might mean being a necessary, sufficient, direct cause. Together with minimal agential involvement, that might suffice for liability to be killed. Substantial agential involvement might mean culpability, which with a relatively slight causal contribution might also suffice for liability." 40 In general, one may agree with Christian Barry and Lars Christie that in establishing the criteria for determining whether combatants' causal contributions to the violation of jus ad bellum are sufficient for grounding their liability to being lethally targeted, a key question to be tackled is that of the relevance to these criteria of the combatants' culpability - if culpability is necessary for liability to defensive harm, then being fully excused will also mean being exempted from liability. ${ }^{41}$ What Barry and Christie propose as a step forward in this debate is to distinguish between unjust soldiers "who are epistemically justified in believing their actions are either morally required or supererogatory [and] those epistemically justified in believing that their act is morally permissible" ${ }^{\prime 42}$ - the former being supposedly less likely to become liable to defensive harm. One must also remember about another possible limitation of the scope of unjust combatants' liability, traditionally presented as stemming from the duress under which at least some of them decide to participate in the war. ${ }^{43}$

\footnotetext{
${ }^{38}$ C. Fabre, Guns, Food, and Liability to Attack in War, Ethics, Vol. 120, No. 1 (October 2009), 61.

${ }^{39}$ C. Fabre, Cosmopolitan war, Oxford University Press, 2012, 72, 77.

${ }^{40}$ S. Lazar, op. cit., 94.

${ }^{41}$ C. Barry and L. Christie, The Moral Equality of Combatants, in: S. Lazar and H. Frowe (ed.), The Oxford Handbook of Ethics of War, Oxford University Press, 2018, 349.

42 Ibid., 353.

${ }^{43}$ Some recent accounts of that excuse are very stringent as for its exculpatory potential. See, e.g., Cecile Fabre, Cosmopolitan war..., op. cit. 73. For Barry and Christie the liability of soldiers operating under duress is relative not to their blameworthiness (which, according to these authors, may be evident regardless of the coercive circumstances of the soldiers' engagement in an armed conflict), but to the actual moral standing of combatants who may potentially take them out: "although the coerced agent who does wrong is blameworthy (i.e. culpable), others are not in a position to blame him since they probably would have done the same were they similarly situated", 357. In the opinion of J. McMahan, the duress involved in conscription may serve as an excuse, but it does not exculpate conscripts taking part in an unjust war: "the belief that acts of war by conscripts are wholly or partially excused presupposes the belief that those acts are wrong". Jeff McMahan, Extremism and Confusion in American Views about the Ethics of War: A Comment on Sagan and Valentino, in: Ethics \& International Affairs, 33, no.4 (2019), 452. As demonstrated by the empirical findings of S. Sagan and B. Valentino, the attitudes of the American public towards unjust combatants who have been coerced into military service are even more rigid: "most Americans do not seem to accept the revisionist idea that soldiers who are forced to fight for a cause they do not support are less morally culpable than enthusiastic volunteers". S. D. Sagan and B. A. Valentino, Just War and Unjust Soldiers: American Public Opinion on the Moral Equality of Combatant, in: Ethics \& International Affairs, 33, no.4 (2019), 428.
} 
While reviewing the above distinctions between different modes of participation in a "classic" unjust war, one should bear in mind that any attempt at developing their direct counterparts for application to the Nazi German type of total war must take into account the essential uniqueness of the latter, i.e., its tactical and strategic orientation toward targeting civilians. The significance of this characteristic for the liability of partakers in such a military operation becomes apparent upon analysis of cases that expose the plausibility of epistemic excuses - or lack thereof - available to unjust combatants. In a hypothetical case of this kind - put forward by Jonathan Quong - a group of "Duped Soldiers" are successfully convinced by their country's totalitarian regime to attack and destroy a village situated on the border of a neighbouring state which they (utterly misled by the regime) believe to be a terrorist camp preparing a dangerous attack. ${ }^{44}$ In discussing the case - in some important respects, analogous to the bombardment of Wielun in the first minutes of World War II - Quong challenges the soldiers' right to deny liability for the attack by appealing to their inculpable ignorance of its unjustified nature. According to Quong, rather than considering a person's liability to defensive harm to be related to the actual facts of the case and/or her hypothetical knowledge of those facts, one should determine the liability in question "by asking what it would be reasonable for others to demand of [the person] given the value of the affected activities, the costs involved, the options available, and the relative harms that others might suffer." 45 However, it must be remembered, as pointed out by Barry and Christie, that the unreasonableness of the attack on civilians in the case of the Duped Soldiers is in the first place contingent upon the self-evident character of the principles of jus in bello: "destroying an entire village in order to take out a terrorist cell is something any soldier, regardless of their mistaken belief in their own just cause, should surely realize is wrong, since it would clearly violate reasonable principles of proportionality." 46 The principle of discrimination, violated in the Nazi bombardment of Wielun, as well as in all the subsequent atrocities committed by the Wehrmacht against Polish civilians, may well be considered even more elementary than the principle of proportionality, and could therefore be thought to ground liability of its direct or indirect violators to a correspondingly greater extent. Consequently, for participant of the Nazi German type of war to be deemed liable to lethal harm, the relevance thresholds imposed on his causal contribution to the anti-civilian atrocities as well as his agential involvement in this contribution should be reduced to the minimum. The role of facilitators of those atrocities can thus reasonably be ascribed not only to soldiers who assist their perpetrators in an obvious, though indirect way, but also to combatants engaged only in regular warfare, provided they possess some knowledge of the systematic violations of jus in bello by their comrades. Exculpating those of them who seriously claim not to understand the moral significance of such acts essentially amounts to denying them the status of rational moral agents.

The third type of culpability related to participation in a total war extends to ordinary, jus-in-bello-abiding combatants who have no knowledge of the actual scale and nature of hostilities inflicted on civilians during the war. Paradoxically, narrow as

\footnotetext{
$\overline{44}$ J. Quong, Rights Against Harm, Proceedings of the Aristotelian Society Supplementary Volume, 89 (2015), 261.

45 Ibid., 265.

${ }^{46}$ C. Barry and L. Christie, op. cit., 352.
} 
this group is, it may include combatants who do causally contribute to killing civilians if this harm can reasonably be qualified as collateral damage resulting from a purely military operation. Defining this kind of culpable contribution to a total war makes it necessary to expand the concept of soldiers' responsibility for breaches of jus in bello by adding to it a specific collective dimension. As opposed to the collectivization of responsibility for the breach of jus ad bellum (in its Walzerian account), the collectivization of responsibility for the systematic violations of elementary war conventions does not exonerate the direct perpetrators of such crimes. Also, the ascription of the latter type of collective responsibility - unlike the ascription of collective responsibility for the breach of jus ad bellum - is not a result of applying a classic individualistic model of moral responsibility (with individual political leaders of the aggressor state charged with the crime of "planning, initiating and waging" the war). The issues related to such a type of collective responsibility have recently been discussed in the field of moral philosophy. As Marion Smiley argues "even in cases where we can locate a great deal of bad behaviour on the part of individual moral agents and ascribe moral responsibility to them for harm, we can still sometimes say that the collective in question has done something wrong that individuals themselves could not do and that renders the collective itself responsible qua collective". One such case is, in Smiley's view, "that of nation states whose military systems appear to be at least partly responsible for the killing of innocents." Although we may try to locate precisely the source of such atrocities (by going up the chain of command), "we will also have to confront the fact there is something about the structure of the collective that will make the killing of innocents likely, even if those participating in the war find the killing of innocents atrocious". 47

In a similar vein, Neta Crawford has developed an account of moral responsibility extending beyond the group of direct perpetrators of war crimes. Though her concept of "systemic atrocity" is meant to denote mostly "foreseeable and preventable", yet - at the same time - "unintended and tragic" violations of the rights of civilians, the terms in which the phenomenon is described imply as one of its causes a widespread prevalence among the members of a military group of a certain type of morally corrupt mentality: "The cause of systemic atrocity is structural to the extent that collectives constrain individual choice and action, as well as psychological/cultural in the sense that individuals possess attitudes of indifference or contempt that are widely shared and that make it difficult to see systemic atrocity even as it is being produced." In the end, while pointing out the underlying reasons for the phenomenon of systemic atrocity, Crawford does include among their ultimate consequences acts of intentional violation of jus in bello: "When the rules of engagement, the weapons available to solders, or military doctrine do not sufficiently allow for discrimination between combatants and non-combatants, the potential exists for systemic atrocity. In addition, when military organizations devalue 'enemy' civilians, systemic atrocity, the intentional killing of civilians (under the rationale that such killing was necessary), and isolated incidents of soldiers 'snapping', may be more likely". ${ }^{48}$ In deciding the question of individual

\footnotetext{
${ }^{47}$ M. Smiley, From Moral Agency to Collective Wrongs: Re-Thinking Collective Moral Responsibility, Journal of Law and Policy 1 (2010), 194-195.

${ }^{48}$ N. Crawford, Individual and Collective Moral Responsibility for Systematic Military Atrocity, in: The Journal of Political Philosophy, Volume 15, Number 2, 2007, 189, 191
} 
blameworthiness resulting from the very participation in such a military undertaking regardless of the level of its direct effectiveness - one should consider arguments analogous to those applying to soldiers' individual contributions to the achievement of wars' strategic aims. One such argument, developed compellingly by Saba Bazargan, ascribes liability for the morally regrettable outcome of an unjust war to both effective and ineffective combatants: "Combatants who do their part in a war - that is, combatants who (effectively or not) act in accordance with roles designed to further the cooperative act of achieving the war's aims - can be complicitously liable for that cooperative act, since such combatants are inclusive authors of that cooperative act. Combatants can bear complicitous liability even if they are ineffective since what grounds their complicitous liability is not their causal contribution to the cooperative act, but the functional relation of their role to that act". ${ }^{49}$ With the replacement of "act of achieving the war's aims" with "act constituting a systematic violation of jus in bello" Bazargan's argument retains all its cogency: whatever their involvement in a military operation bringing about the systematic perpetration of war crimes, all the soldiers participating in this operation share liability for the systemic (i.e., going beyond the initiative of particular individuals) nature of these crimes. Stringent as it is, the rule extends also to soldiers involved only in ordinary combat - there can be no doubt about "the functional relation of their role" to the emergence of circumstances facilitating the crimes in question.

It is obvious that the degree of individual responsibility of each German soldier for the systematic atrocities committed against Polish and Jewish civilians in September 1939 must have been different depending on the specificity of individual cases. Most of them were probably able to find a more or less reasonable "excuse" for their participation in the war - equivalent to being released from the necessity of incurring any penal consequences of that engagement. However, the very participation in a total war - one of the aims of which was the systematic violation of the rules of jus in bello - can in no way be morally justified (morally permissible). ${ }^{50}$ It is thus only an excuse - not a justification - that is available to "ordinary" participants in such a war (unburdened by direct involvement in war crimes), including those who may claim to have been completely ignorant of its true nature.

\section{Individual Responsibility of Soldiers for the Participation in a Total War}

The possibility of attributing to individual soldiers some level of moral responsibility for their participation in war - regardless of any circumstances which may lead to a possible limitation of that responsibility - is a prerequisite for their preserving, at least to a minimal extent, the status of subjects of their own actions. In Walzer's view, the moment a person engages (voluntarily or forced by the state) in an armed conflict marks his/her conversion into a "human instrument" of his/her state. It is only in this role that $\mathrm{s}$ /he is to obtain the privilege (or accept the burden) of moral equality with all

\footnotetext{
${ }^{49}$ S. Bazargan, Complicitous liability in war, in: Philosophical Studies, (2013) 165, 188.

${ }^{50}$ For the difference between "justification" and "excuse", see: J. McMahan, The Ethics of Killing in War, Ethics 114 (2004), 698-702.
} 
the other combatants - especially those fighting on the opposite side of the frontline. "[Soldiers] - as argued by Walzer - are most likely to believe that their wars are just, and while the basis of that belief is not necessarily rational inquiry but, more often, a kind of unquestioning acceptance of official propaganda, nevertheless they are not criminals; they face one another as moral equals." ${ }^{, 51}$ Moral equality of combatants turns out to be, therefore, an equality of individuals who have been essentially deprived of their key attributes as rational moral agents. Acquiring this dubious privilege is to be preceded by the "switching off" of one's basic intellectual and moral capacities which are indispensable in the assessment of one's actions.

It is difficult to agree with Walzer that such a large-scale suspension of people's key prerogatives as autonomous moral subjects may take place in any political community in a situation generating the necessity to systematically risk one's own life/take the lives of other people. On the contrary, due to the utmost extreme nature of the challenges related to one's engagement in warfare, what might be expected of most of prospective combatants is to mobilize at least part of the intellectual and moral resources constituting their personal autonomy as human individuals. What is notable, it is Walzer himself who expects combatants to permanently preserve the ability to make a certain type of moral judgments: he identifies this with what is generally attributed to soldiers - and repeatedly confirmed by their behavior during military conflicts - i.e., their respect for jus in bello. However, the very fact of soldiers' general compliance with the rules of jus in bello may be viewed as substantial evidence of the essential functionality of moral consciousness in the context of a military conflict. It may even be argued that the conditions in which a combatant is expected to demonstrate his adherence to the rules of jus in bello are significantly harsher than those surrounding his possible contemplation of the justifiabilty of the reasons behind his country's going to war. The case for acknowledging some level of responsibility of soldiers for violations of jus ad bellum is made by Cecile Fabre: "If epistemic uncertainty in the fog of war does not constitute a justification for a wrongful killing [of non-combatants], it is not clear why it would constitute a justification for taking part in an unjust war when the decision so to act can be made in the safety of the barracks". 52 The most direct (albeit somewhat disturbing) argument against suspending a war's jus ad bellum qualification as a matter of concern for ordinary soldiers stems from the latest study of S. D. Sagan and B. A. Valentino, whose findings show that a significant number of Americans are ready either to excuse violators of the rules of jus in bello (provided the cause of their war is just) or to condemn soldiers complying with these rules if the cause they are fighting for is unjust. ${ }^{53}$ Based on what seems to be a complete reversal of the central tenet of Walzer's theory, combatants' respect for jus ad bellum may thus be (wrongly) considered even more significant than their compliance with jus in bello.

It should also be noted that what Walzer regards as the necessary social embedment of all types of moral beliefs seems also to undergird one's sense of loyalty to one's own state. ${ }^{54}$ In his response to Sagan and Valentino he emphasizes the need to construe

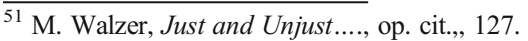

52 C. Fabre, Cosmopolitan war..., op. cit., 74.

${ }^{53}$ S. D. Sagan and B. A. Valentino, op. cit. 433.

54 „I don't mean to suggest that our judgments, even over time, have an unambiguous collective form. Nor, however, are they idiosyncratic and private in character. They are socially patterned, and the patterning is religious, cultural, and political as well as legal. The task of the moral theorist is to study the pattern as a whole, reaching for its deepest reasons.” M. Walzer, Just and Unjust...., op. cit., 45.
} 
basic intuitions underlying jus in bello as part of "the real-life moral intuitions of the men and women who are, whether they like it or not, engaged", being "on this side or that one", or feeling "close to this side or that one". ${ }^{55}$ Viewed in this way, the intuitions cannot be entirely separated from the emotional content of one's membership in a political community. On the contrary, it is this primordial attachment to the community's way of life that may be thought to inform the intuitions about the universally binding nature of jus in bello. Not surprisingly, while criticizing Sagan and Valentino's intentional avoidance of employing any historically embedded survey questions, Walzer declares openly that he "would not be afraid of scenarios that make room for patriotic favoritism, since this might lead respondents to put a very high value on American lives and then recognize that valuations of this kind have necessary extensions - for both moral and practical reasons [...]". 56 Any attempt to simultaneously juxtapose soldiers' unwavering commitment to the community-based moral norms with their alleged propensity to unreflectively surrender to the "official war propaganda" of their state leaders is not, therefore, entirely plausible. ${ }^{57}$

In the case of the historically documented violations of war conventions by Wehrmacht troops operating in Poland in 1939, the separation of soldiers' responsibility for the violation of jus ad bellum from their responsibility for the infringements of jus in bello proves particularly problematic. Shielding individual German soldiers from the normative impact of the fundamental ban on state-to-state aggression inevitably calls into question the possibility of simultaneously applying to their actions the standard set of rules defining the scope and scale of permissible employment of military violence (the rules of jus in bello). The difficulty of preserving the separation between the two perspectives becomes evident when one attempts to morally assess the actions of the German airmen discharging bombs on the sleeping inhabitants of Wielun. According to the canonical version of Walzer's theory, the act in question would have to be condemned as a violation of the basic war convention, and, at the same time, regarded as a morally permissible act of executing the order to initiate the attack on the Polish state. This most disconcerting paradox, one pertaining to most of the atrocities committed by the German army against Polish civilians in September 1939, takes on special meaning in light of Hitler's infamous speech delivered to the senior officers of

\footnotetext{
${ }^{55}$ M. Walzer, On Reciprocity and Practical Morality: A Response to Sagan and Valentino, in: Ethics \& International Affairs, 33, no.4 (2019), 446-447.

${ }^{56}$ Ibid., 447. Surprisingly, he is joined in this preference for a cultural-identity-based examination of moral intuitions by Jeff McMahan. Jeff McMahan, Extremism and Confusion in American Views about the Ethics of War: A Comment on Sagan and Valentino, in: Ethics \& International Affairs, 33, no.4 (2019), 460.

${ }^{57}$ Even if one agrees with Walzer that a surrender to the pro-war propaganda is the most common factor behind a person's willing engagement in an armed conflict, in evaluating such acts it is important to consider the actual content of particular instances of such propaganda. It seems reasonable that one should take into account the key differences between the propaganda messages of the opposing sides of a conflict - for example, between the Third Reich's leaders' urging the German soldiers to sacrifice their lives during the attack on Poland on September 1, 1939, and the Polish government officials' inciting their fellow citizens to the defense of their country in August and September 1939. There seems to be no reason why these differences should not translate into a completely different evaluation of one's participation in the first stage of WWII on one or the other side of the frontline. One should also consider the possibility - fully substantiated in a considerable number of cases - of a thoroughly conscious, rationally justified decision to take part in a defensive (i.e. morally justified) war. It is difficult to envisage any plausible argument for holding that such an attitude should be regarded as morally equivalent to the "blind acceptance" of the belligerent propaganda of the aggressor state.
} 
the Wehrmacht on August 22, 1939. Emphasizing the strategic aims of the upcoming invasion of Poland - to be achieved by means of exterminating the local population ${ }^{58}$ the speech manifested the essential ideological dimension of the imminent military operation, standing in direct contrast to the most basic principles of jus in bello. ${ }^{59} \mathrm{With}$ the directly articulated orientation of warfare towards the destruction of the biological substance of the conquered political community, releasing soldiers from moral responsibility for participating in such a war may also mean releasing them from the obligation to observe any rules restricting the use of military violence.

It is notable that the extension of the list of "classic" objectives of war with the strategic aims of the German campaign of September 1939 - directly undermining the basic war conventions - was accompanied by the official proclamation of the universal validity of these conventions. The paradox was emphasized by Szymon Datner (a Polish historian of Jewish origin), who presented the document entitled "The 10 Commandments of the German Soldier on the Manner of Waging War", hinted at by German field officer Erhard Milch during his testimony at the Nuremberg Trial. The booklet contained a brief summary of the key rules of jus in bello - including the principle of the inviolability of life and property of civilian population - and was attached, according to Milch's testimony, to the military ID of every German soldier. ${ }^{60}$ In this way, the elementary moral norms regulating the conduct of war, left principally unchanged as an element of the pro-war propaganda of the Nazis, maintained the status of perfectly valid directives addressed to each soldier of the Wehrmacht. At the same time, they were "complemented" by their exact opposite, encoded in the most aberrant restatement of jus ad bellum (one might regard the Nazi ideology - and the ensuing conception of total war - as such a horrific travesty of the idea of international justice). As a consequence, the killing of Polish and Jewish civilians might have seemed to be an act of a dual nature: engaging in it - even with the ultimate recognition of its twofold criminal character - gave individual soldiers the opportunity not to assume direct responsibility for the crimes which they committed. The idea of attributing violations

\footnotetext{
58 " [...] our war aim does not consist in reaching certain lines, but in the physical destruction of the enemy. Accordingly, I have placed my death-head formation in readiness - for the present only in the East - with orders to them to send to death mercilessly and without compassion, men, women, and children of Polish derivation and language. Only thus shall we gain the living space (Lebensraum) which we need." Lochner (1943), 2. The quote is the English translation of the original German document received by the author in August, 1939, during his stay in Berlin. For the German original, see: Akten zur deutschen Auswartigen Poltik 1918-1945. Aus dem Archiv des Deutschen Auswartigen Amtes [ADAP], Baden-Baden 1956, Seria D, Band 7, 171-172, note 1; in: Spojrzenie na Polski Wrzesień 1939, op. cit.

59 The analysis of the profound significance of Nazi ideology for the actual course of the campaign of September 1939 was undertaken by A. B. Rossino: A. B. Rossino, Hitler strikes Poland. Blitzkrieg, Ideology and Atrocity, Kansas City 2003. The deep entanglement of the Wehrmacht in the evolution of the Nazi ideology and its practical implementation is also indicated by J. Böhler: J. Böhler, Auftakt zum Vernichtungskrieg..., op. cit. 22, 28-29.

${ }^{60} 10$ Gebote für die Kriegsführung des deutschen Soldaten. Der Prozess gegen die Hauptkriegsverbrecher vor dem Internationalen Militargerichtshof, Nürnberg 1947, vol. IX, 100 -101, quoted by Sz. Datner, op. cit., 28-29. Point 7 of the brochure, highlighted by Datner in a special way, reads as follows: "7. The civilian population is inviolable. The soldier must not rob or destroy their property. Particular attention should be paid to historical monuments and objects of worship as well as buildings used for the cultivation of art, science and charity. The provisions from the people in kind and services can only be enforced on the orders of superiors and in exchange for a suitable compensation."
} 
of jus ad bellum exclusively to political entities, i.e., aggressor states, may unfortunately be used to legitimize such an interpretation.

Any attempt to modify this conceptual design in order to highlight a possible individual responsibility related to one's participation in an unjust war must take into account, in accordance with Walzer's requirement, the real complication of historical armed conflicts. The military attack of the Nazi Germany on Poland in 1939, together with the Polish Army's defensive war, appear to be an exceptionally suitable background for examining the validity of Walzer's thesis about the moral equality of soldiers fighting on both sides of the frontlines of all kinds of wars. The analysis of a number of pivotal events in the German military campaign of September 1939 reveals the controversial aspects of this claim - one of the main assumptions of Walzer's just war theory. Working out and justifying its appropriate modifications will amount to challenging the author of Just and Unjust Wars on his most consistently held position. The task is still open for contemporary researchers dealing with the ethics of war. ${ }^{61}$

Open Access This article is licensed under a Creative Commons Attribution 4.0 International License, which permits use, sharing, adaptation, distribution and reproduction in any medium or format, as long as you give appropriate credit to the original author(s) and the source, provide a link to the Creative Commons licence, and indicate if changes were made. The images or other third party material in this article are included in the article's Creative Commons licence, unless indicated otherwise in a credit line to the material. If material is not included in the article's Creative Commons licence and your intended use is not permitted by statutory regulation or exceeds the permitted use, you will need to obtain permission directly from the copyright holder. To view a copy of this licence, visit http://creativecommons.org/licenses/by/4.0/.

\section{References}

10 Gebote für die Kriegsführung des deutschen Soldaten. (1967). Der Prozess gegen die Hauptkriegsverbrecher vor dem Internationalen Militargerichtshof, Nürnberg 1947, vol. IX, 100-101, quoted by Sz. Datner, 55 dni Wehrmachtu w Polsce. Zbrodnie na polskiej ludności cywilnej w okresie 1.XI - 25. X. 1939. Warszawa: Wydawnictwo Ministerstwa Obrony Narodowej.

\footnotetext{
${ }^{61}$ One may wonder if questioning the principle of the moral equality of soldiers may be aimed at achieving any practical results, i.e., ones that will not be reducible to what McMahan calls the 'deep morality of war". The latter, according to Walzer, has no practical value - endorsing it may allow one e.g., to criticize soldiers who knowingly participate in unjust wars - whereas Walzer's concern is "with what soldiers can rightly do or not do in practice" (my personal communication with the author). While agreeing with Walzer as to the obvious constraints on implications arising from the rejection of the principle in question, one might insist that the acknowledgement of a possible moral inequality of soldiers could have practical consequences in the post bellum arrangements, e.g., in the extension of the list of obligations imposed on a defeated aggressor state. These additional obligations may include, e.g., facilitating detailed historical research into the (conduct of) war, pursuing adequate public education policy related to the war, promoting effective commemoration of the war victims (including victims of military violence, preceding/occurring simultaneously with the occupation atrocities), etc. Unfortunately, such obvious tasks of defeated aggressor states are not always fulfilled spontaneously: in his paper published in Polish in 2011 Joseph Böhler writes that "there is no study published in the German language on the participation of the German Luftwaffe in the war against Poland in 1939 and the destruction of hundreds of Polish cities and towns carried out by the Nazi-German air force" (J. Böhler, Wojna z Polska w 1939 r. w historiografii zachodnioniemieckiej, op. cit., 34). Meanwhile, an intense debate was focused in Germany on the book devoted to the Allied bombing of German cities (Jörg Friedrich, Der Brand, Deutschland im Bombenkrieg 1940-1945, Propyläen Verlag, Munich 2002; English translation: The Fire: The Bombing of Germany, 1940-1945, transl. by Allison Brown, Columbia University Press, New York, 2006), whose author points to the summer of 1940 as the alleged beginning of direct strategy-based anti-civilian violence perpetrated by military aircraft (See: J. Friedrich, Der Brand, Deutschland im Bombenkrieg 1940-1945, Ullstein Buchverlage, Berlin 2004, 69-73) .
} 
Anscombe, E. (1961). War and Murder. In W. Stein (Ed.), Nuclear weapons: A catholic response (pp. 45-62). London and New York: Sheed and Ward.

Barry, C., \& Christie, L. (2018). The Moral Equality of Combatants. In S. Lazar \& H. Frowe (Eds.), The Oxford handbook of ethics of war (pp. 339-357). Oxford: Oxford University Press.

Bazargan, S. (2013). Complicitous liability in war. Philosophical Studies, 165, 177-195.

Benbaji, Y. (2009). The war convention and the moral division of labour. The Philosophical Quarterly, 59(337), 592-617.

Böhler, J. (2006). Auftakt zum Vernichtungskrieg. Die Wehrmacht in Polen 1939. Frankfurt am Main: Fischer.

Böhler, J. (2009). Der Überfall. Deutschlands Krieg gegen Polen. Frankfurt: Eichborn.

Böhler, J. (2011). In T. Kondracki (Ed.), Wojna z Polska w 1939 r. w historiografii zachodnioniemieckiej, in: Spojrzenie na Polski Wrzesień 1939 (pp. 23-34). Warszawa: Wydawnictwo Neriton.

Crawford, N. (2007). Individual and collective moral responsibility for systematic military atrocity. The Journal of Political Philosophy, 15(2), 187-212.

Datner, S. (1967). 55 dni Wehrmachtu w Polsce. Zbrodnie na polskiej ludności cywilnej w okresie 1.XI-25. X. 1939 [55 days of the Wehrmacht in Poland. Crimes against the Polish civilian population in the period: September 1 to October 25, 1939]. Warszawa: Wydawnictwo Ministerstwa Obrony Narodowej.

Davies N. (2009). We must not forget the real causes of the war. In: The Independent, 28.08.2009, http://www.independent.co.uk/voices/commentators/we-must-not-forget-the-real-causes-of-the-war1778973.html. Accessed 30 Apr 2020.

Fabre, C. (2009). Guns, food, and liability to attack in war. Ethics, 120(1), 36-63.

Fabre, C. (2012). Cosmopolitan war. Oxford: Oxford University Press.

Friedrich, J. (2004). Der Brand, Deutschland im Bombenkrieg 1940-1945. Berlin: Ullstein Buchverlage.

Lazar, S. (2015). Sparing civilians. Oxford: Oxford University Press.

Lochner, L. P. (1943). What About Germany? New York: Dodd, Mead \& Co.

McMahan, J. (2004). The ethics of killing in war. Ethics, 114, 693-733.

McMahan, J. (2006). Killing in war: A reply to Walzer. Philosophia, 34, 47-51.

McMahan, J. (2019). Extremism and confusion in American views about the ethics of war: A comment on Sagan and Valentino. Ethics \& International Affairs, 33(4), 451-463.

Olejnik, T. (2014). Wieluńska hekatomba. Poczatek wojny totalnej [The Hecatomb of Wieluń. The beginning of a total war]. Wieluń: Muzeum Ziemi Wieluńskiej.

Parsons, G. (2012). Public war and the moral equality of combatants. Journal of Military Ethics, 11(4), $299-317$.

Quong, J. (2015). Rights against harm. Proceedings of the Aristotelian Society Supplementary Volume, 89, 249-266.

Reichberg, G. M. (2013). The moral equality of combatants - a doctrine in classical just war theory? A response to Graham Parsons. Journal of Military Ethics, 12(2), 181-194.

Rigstad, M. (2017). Putting the war Back in just war theory. A critique of examples. Ethical Perspectives, 24(1), 123-144.

Rossino, A. B. (2003). Hitler strikes Poland. Blitzkrieg, ideology and atrocity. Lawrence: University Press of Kansas.

Sagan, S. D., \& Valentino, B. A. (2019). Just war and unjust soldiers: American public opinion on the moral equality of combatant. Ethics \& International Affairs, 33(4), 411-444.

Smiley, M. (2010). From moral agency to collective wrongs: Re-thinking collective moral responsibility. Journal of Law and Policy, 1, 171-202.

Snyder, T. (2010). Bloodlands. Europe between Hitler and Stalin. New York: Basic Books.

Statman, D. (2006). Supreme emergencies revisited. Ethics, 117, 58-79.

Steinhoff, U. (2008). Debate: Jeff McMahan on the moral inequality of combatants. The Journal of Political Philosophy, 16(2), 220-226.

Steinhoff, U. (2012). Rights, liability, and the moral equality of combatants. Journal of Ethics, 16, 339-366.

Toner, C. (2005). Just war and the supreme emergency exemption. The Philosophical Quarterly, 55(221), 545-561.

Walzer, M. (2006). Response to McMahan's paper. Philosophia, 34, 43-45.

Walzer, M. (2015). Just and unjust wars. New York: Basic Books.

Walzer, M. (2017). Just war and holy war. Again. Ethical Perspectives, 24(1), 7-20.

Walzer, M. (2019). On reciprocity and practical morality: A Response to Sagan and Valentino. Ethics \& International Affairs, 33(4), 445-450.

Publisher's Note Springer Nature remains neutral with regard to jurisdictional claims in published maps and institutional affiliations. 